\title{
AMPA Receptor Calcium Permeability, GluR2 Expression, and Selective Motoneuron Vulnerability
}

\author{
Wim Vandenberghe, ${ }^{1,2}$ Wim Robberecht, ${ }^{2}$ and James R. Brorson ${ }^{1}$ \\ 1 Department of Neurology, The University of Chicago, Chicago, Illinois 60637, and ${ }^{2}$ Department of Neurology, University \\ of Leuven, 3000 Leuven, Belgium
}

\begin{abstract}
AMPA receptor-mediated excitotoxicity is proposed to play a major pathogenic role in the selective motoneuron death of amyotrophic lateral sclerosis. Motoneurons have been shown in various models to be more susceptible to AMPA receptormediated injury than other spinal neurons. It has been hypothesized that this selective vulnerability of motoneurons is caused by the expression of highly $\mathrm{Ca}^{2+}$-permeable AMPA receptors and a complete or relative lack of the AMPA receptor subunit Glu receptor 2 (GluR2). The aim of this study was to quantify the relative $\mathrm{Ca}^{2+}$ permeability of AMPA receptors and the fractional expression of GluR2 in motoneurons by combining whole-cell patch-clamp electrophysiology and single-cell RT-PCR and to compare these properties with those of dorsal horn neurons. Spinal motoneurons and dorsal horn neurons were isolated from embryonic rats and cultured on spinal astrocytes. As in previous studies, motoneurons were significantly more vulner-
\end{abstract}

Amyotrophic lateral sclerosis (ALS) is a fatal neurodegenerative disease characterized pathologically by the predominant loss of motoneurons. A growing body of circumstantial evidence suggests that AMPA receptor-mediated excitotoxicity contributes to the motoneuron death of ALS (Rothstein, 1996; Shaw and Ince, 1997). Motoneurons are more vulnerable to AMPA receptor agonists than other spinal neurons, both in vivo (Hugon et al., 1989; Ikonomidou et al., 1996) and in organotypic and dissociated spinal cord cultures (Rothstein et al., 1993; Carriedo et al., 1996; Bar-Peled et al., 1999). The mechanisms underlying this selective vulnerability of motoneurons to AMPA receptor overactivation are poorly understood.

AMPA receptors are cation-conducting complexes composed of various combinations of four subunits [Glu receptor 1 (GluR1) to GluR4 or GluR-A to GluR-D; Seeburg, 1993; Hollmann and Heinemann, 1994]. AMPA receptors lacking GluR2 have a high relative $\mathrm{Ca}^{2+}$ permeability $\left(\mathrm{P}_{\mathrm{Ca}^{2+}} / \mathrm{P}_{\text {monovalent }}\right)$, whereas $\mathrm{P}_{\mathrm{Ca}^{2+}}$ $\mathrm{P}_{\text {monovalent }}$ of receptors containing GluR2 is very low (Hollmann et al., 1991). This effect of GluR2 on AMPA receptor $\mathrm{P}_{\mathrm{Ca}^{2+}}$ $\mathrm{P}_{\text {monovalent }}$ is attributable to the presence of an arginine in its

\footnotetext{
Received Sept. 3, 1999; accepted Oct. 15, 1999.

This work was supported by the ALS Association and by National Institute of Neurological Disease and Stroke Grant NS36260 (J.R.B.). W.V. is supported as Aspirant of the Fund for Scientific Research (FWO)-Flanders. W.R. is supported as Clinical Investigator of the FWO-Flanders and by the Research Council of the University of Leuven. We thank Dr. Stephen Heinemann and Dr. Peter Seeburg for providing AMPA receptor subunit cDNA clones, Dr. Vytautas Bindokas for help with photographs, and Dr. Doris Patneau for discussion.

Correspondence should be addressed to Dr. James R. Brorson, Department of Neurology, MC2030, The University of Chicago, 5841 South Maryland Avenue, Chicago, IL 60637. E-mail: jbrorson@neurology.bsd.uchicago.edu.

Copyright (C) 1999 Society for Neuroscience 0270-6474/99/200123-10\$15.00/0
}

able to AMPA and kainate than dorsal horn neurons. However, all motoneurons expressed GluR2 mRNA ( $40 \%$ of total AMPA receptor subunit $m R N A)$, and their AMPA receptors had intermediate whole-cell relative $\mathrm{Ca}^{2+}$ permeability $\left(\mathrm{P}_{\mathrm{Ca}^{2+}} / \mathrm{P}_{\mathrm{Cs}^{+}} \sim\right.$ 0.4). AMPA receptor $\mathrm{P}_{\mathrm{Ca}^{2+}} / \mathrm{P}_{\mathrm{Cs}}{ }^{+}$and the relative abundance of GluR2 varied more widely in dorsal horn neurons than in motoneurons, but the mean values did not differ significantly between the two cell populations. GluR2 was virtually completely edited at the $Q / R$ site both in motoneurons and dorsal horn neurons. These results indicate that the selective vulnerability of motoneurons to AMPA receptor agonists is not determined solely by whole-cell relative $\mathrm{Ca}^{2+}$ permeability of AMPA receptors.

Key words: amyotrophic lateral sclerosis; excitotoxicity; kainate; dorsal horn; rat; culture pore-forming segment, in a position occupied by glutamine in the other AMPA receptor subunits (Hume et al., 1991; Burnashev et al., 1992). This critical arginine residue is created at the premRNA stage by RNA editing (Sommer et al., 1991). The relative $\mathrm{Ca}^{2+}$ permeability of native AMPA receptors in neurons is inversely correlated with the relative abundance of edited GluR2 and ranges from almost 0 to $>2$ in different neuronal cell types (Jonas et al., 1994; Geiger et al., 1995).

Direct $\mathrm{Ca}^{2+}$ entry through AMPA receptors is capable of triggering neuronal death (Brorson et al., 1994). Therefore, the divergence in relative $\mathrm{Ca}^{2+}$ permeability of AMPA receptors between different neuronal cell types could be an important determinant of selective neuronal vulnerability (PellegriniGiampietro et al., 1997). It has been proposed that the selective vulnerability of motoneurons to AMPA receptor agonists might result from expression of highly $\mathrm{Ca}^{2+}$-permeable AMPA receptors and an absence or relative lack of GluR2 in this cell type (Williams et al., 1997; Shaw and Ince, 1997). A majority of spinal motoneurons have been demonstrated qualitatively to possess $\mathrm{Ca}^{2+}$-permeable AMPA receptors by means of kainate (KA)activated $\mathrm{Co}^{2+}$ uptake, a histochemical technique (Carriedo et al., 1996; Vandenberghe et al., 1998a; Bar-Peled et al., 1999). Quantitative measurements of relative $\mathrm{Ca}^{2+}$ permeability of AMPA receptors in motoneurons have not been reported.

Numerous authors have qualitatively assessed GluR2 expression in spinal motoneurons using in situ hybridization and immunocytochemistry, but results have been conflicting. Most groups found evidence of GluR2 mRNA and protein expression in rat and human motoneurons (Furuyama et al., 1993; Tölle et al., 1993; Pellegrini-Giampietro et al., 1994; Jakowec et al., 1995; 
Tomiyama et al., 1996; Virgo et al., 1996; Petralia et al., 1997; Morrison et al., 1998; Vandenberghe et al., 1998a; Grossman et al., 1999), but an absence of GluR2 was reported in two studies (Williams et al., 1997; Bar-Peled et al., 1999). Quantitative measurements of the amount of GluR2 relative to the other AMPA receptor subunits in motoneurons have not been performed.

The aim of the present study was twofold: first, to quantify the relative $\mathrm{Ca}^{2+}$ permeability of AMPA receptors and the relative abundance of GluR2 in motoneurons by combining whole-cell patch-clamp electrophysiology and single-cell RT-PCR; and second, to compare these parameters between motoneurons and other spinal neurons to determine whether these properties can account for the selective vulnerability of motoneurons to AMPA receptor agonists.

\section{MATERIALS AND METHODS}

Cell cultures. Motoneurons were cultured as previously described in detail (Vandenberghe et al., 1998a,b), with minor modifications. In brief, spinal cords were dissected from 15-d-old Holtzmann rat embryos (sperm-positive day $=$ day 1$)$. Procedures followed were in accordance with a protocol approved by the University of Chicago Institutional Animal Care and Use Committee. A motoneuron-enriched neuronal population was purified from the ventral spinal cord by centrifugation on a $6.5 \%$ metrizamide (Sigma, St. Louis, MO) cushion and was cultured in immediate contact with a spinal astrocytic feeder layer, which had been pre-established on $15 \mathrm{~mm}$ round glass coverslips. The neuronal culture medium consisted of L15 (Life Technologies, Grand Island, NY) supplemented with glucose $(3.6 \mathrm{mg} / \mathrm{ml})$, progesterone $(20 \mathrm{nM})$, insulin $(5$ $\mu \mathrm{g} / \mathrm{ml})$, putrescine $(0.1 \mathrm{mM})$, conalbumin $(0.1 \mathrm{mg} / \mathrm{ml})$, sodium selenite (30 nM), penicillin $(100 \mathrm{IU} / \mathrm{ml})$, streptomycin $(100 \mu \mathrm{g} / \mathrm{ml}), 2 \%$ horse serum (Life Technologies), 0.2\% (w/v) sodium bicarbonate, and 5\% chick embryo extract (Life Technologies).

Dorsal horn neurons were dissociated from the dorsal half of the spinal cord. The preparation procedure was exactly the same as for the motoneurons, except that the metrizamide centrif ugation step was omitted. Dorsal horn neurons were seeded on pre-established spinal astrocytic feeder layers at a density of $3000 / \mathrm{cm}^{2}$ and cultured in identical conditions as the motoneurons.

All cultures were kept in a $6 \% \mathrm{CO}_{2}$ humidified incubator at $37^{\circ} \mathrm{C}$. Neurons were used for experiments between 10 and $15 \mathrm{~d}$ in vitro.

Immunocytochemistry. Peripherin and SMI-32 immunostaining was performed as previously described (Vandenberghe et al., 1998a,b). Neuronal cell body diameter (defined as the largest diameter of the soma) was quantified using a computer image analysis system (Quantimet 500; Leica, Cambridge, UK).

Toxicity experiments. Motoneuron-enriched cultures and dorsal horn cultures were exposed to excitotoxins for $24 \mathrm{hr}$ at $37^{\circ} \mathrm{C}$ in a $6 \% \mathrm{CO}_{2}$ incubator, using an exposure medium of L15 supplemented with glucose $(3.6 \mathrm{mg} / \mathrm{ml})$ and sodium bicarbonate $(0.15 \%, \mathrm{w} / \mathrm{v})$. The NMDA receptor antagonist MK-801 $(10 \mu \mathrm{M})$ was added during all agonist exposures. All neurons present on one coverslip were counted immediately before and after excitotoxin exposure under phase-contrast optics. All cells of neuronal morphology, without vacuolar inclusions and with intact neurites longer than two cell body diameters, were taken into account. Overall neuronal survival was determined as the ratio of the number of neurons present at the end of the exposure to the number of neurons before exposure and was normalized to the survival in negative controls treated with exposure medium without agonist. Cultures were subsequently fixed and stained with anti-peripherin. Motoneuron survival in each condition was calculated as the overall survival in that condition times the percent peripherin $(+)$ cells in that condition, divided by the percent peripherin $(+)$ neurons in the negative control. Dorsal horn neuron survival was calculated analogously, using overall survival and percent peripherin(-) neurons. All countings were performed by an observer blinded to the treatment protocol.

Electrophysiology. Whole-cell voltage-clamp experiments were performed using somatically placed, dichlorodimethylsilane- and diethylpyrocarbonate (DEPC)-treated borosilicate pipettes without tip polishing (Brorson et al., 1999). Four microliters of intracellular solution were back-filled into the pipette after tip filling. Pipettes had a resistance of $1.8-2.5 \mathrm{M} \Omega$ when filled with intracellular solution. The reference electrode was connected to the bath by means of a $3 \mathrm{~mm} \mathrm{KCl-agar} \mathrm{bridge.}$
Cells were accepted for study if a stable seal formed with a whole-cell resistance of at least $120 \mathrm{M} \Omega$ and access resistance of $<10 \mathrm{M} \Omega$. Responses were recorded using an Axopatch 1D amplifier (Axon Instruments, Foster City, CA). All recordings were performed at room temperature. All surfaces of the patch-clamp setup were wiped with $70 \%$ ethanol, and gloves were worn during patch clamping.

The intracellular solution consisted of $120 \mathrm{~mm} \mathrm{CsF}, 3 \mathrm{mM} \mathrm{MgCl}_{2}, 5$ mM EGTA, and $10 \mathrm{~mm}$ HEPES, pH adjusted to 7.25 with $12 \mathrm{~mm} \mathrm{CsOH}$, and was DEPC-treated and autoclaved. The usual extracellular perfusion buffer contained $145 \mathrm{~mm} \mathrm{NaCl}, 3 \mathrm{~mm} \mathrm{KCl}, 2 \mathrm{~mm} \mathrm{CaCl}_{2}, 1 \mathrm{~mm}$ $\mathrm{MgCl}_{2}, 10 \mathrm{~mm}$ HEPES, and $10 \mathrm{~mm}$ glucose, $\mathrm{pH} 7.40$ with $\mathrm{NaOH} . \mathrm{Ca}^{2+}$ permeability of AMPA receptors was measured in $\mathrm{Na}^{+}$-free extracellular solutions containing either 15 or $50 \mathrm{mM} \mathrm{Ca}^{2+}$. The $15 \mathrm{mM} \mathrm{Ca}^{2+}$ solution consisted of $12.8 \mathrm{mM} \mathrm{CaCl}_{2}, 2.2 \mathrm{mM} \mathrm{Ca}(\mathrm{OH})_{2}, 10 \mathrm{~mm}$ glucose, $10 \mathrm{~mm}$ HEPES, and $240 \mathrm{~mm}$ sucrose (osmolarity, $315 \mathrm{mOsm} / \mathrm{l} ; \mathrm{pH}$ 7.4). The $50 \mathrm{~mm} \mathrm{Ca}^{2+}$ solution consisted of $47.8 \mathrm{mM} \mathrm{CaCl}_{2}, 2.2 \mathrm{~mm} \mathrm{Ca}(\mathrm{OH})_{2}$, $10 \mathrm{~mm}$ glucose, $10 \mathrm{~mm}$ HEPES, and $147 \mathrm{~mm}$ sucrose (osmolarity, 315 $\mathrm{mOsm} / \mathrm{l} ; \mathrm{pH}$ 7.4). Extracellular solutions were supplemented with MK$801(10 \mu \mathrm{M})$, tetrodotoxin $(0.5 \mu \mathrm{M})$, and $\mathrm{Cd}^{2+}(100 \mu \mathrm{M})$ to block NMDA receptors, voltage-gated $\mathrm{Na}^{+}$channels, and $\mathrm{Ca}^{2+}$ channels, respectively.

Cells were held at a membrane potential of $-80 \mathrm{mV}$, and $I-V$ relationships were generated with test potentials from -100 to $+20 \mathrm{mV}$ by $10 \mathrm{mV}$ intervals, with solenoid valve-based application of agonists via a theta tube applicator. For each cell, the $I-V$ curve recording in $50 \mathrm{~mm}$ $\mathrm{Ca}^{2+}$ was bracketed between $2 I-V$ curve recordings in $15 \mathrm{mM} \mathrm{Ca}^{2+}$. Leak current before agonist application was subtracted from agonistevoked steady-state current at each potential. The permeability ratio $\mathrm{P}_{\mathrm{Ca}^{2+}} / \mathrm{P}_{\mathrm{Cs}^{+}}$was calculated from the reversal potential $\left(\mathrm{E}_{\mathrm{r}}\right)$ in $\mathrm{Na}^{+}$-free solution according to the extended constant field equation (Mayer and Westbrook, 1987):

$$
\mathrm{E}_{\mathrm{r}}=(R T / F) \ln \left\{\left[-b+\left(b^{2}-4 a c\right)^{1 / 2}\right] / 2 a\right\},
$$

where

$$
\begin{aligned}
& a=\left[\mathrm{Cs}^{+}\right]_{\mathrm{i}}+4\left(\mathrm{P}_{\mathrm{Mg}^{2+}} / \mathrm{P}_{\mathrm{Cs}^{+}}\right)\left[\mathrm{Mg}^{2+}\right]_{\mathrm{i}}, \\
& b=\left[\mathrm{Cs}^{+}\right]_{\mathrm{i}} \\
& c=-4\left(\mathrm{P}_{\mathrm{Ca}^{2+}} / \mathrm{P}_{\mathrm{Cs}^{+}}\right)\left[\mathrm{Ca}^{2+}\right]_{\mathrm{e}},
\end{aligned}
$$

and $R, T$, and $F$ have their conventional meanings. Ion activities were used. Activity coefficients were calculated from the Debye-Hückel equation (Dean, 1992) to be 0.718 for $\mathrm{Cs}^{+}$and 0.416 for $\mathrm{Mg}^{2+}$ in the intracellular solution, 0.496 for $\mathrm{Ca}^{2+}$ in the $15 \mathrm{mM} \mathrm{Ca}^{2+}$ solution, and 0.357 for $\mathrm{Ca}^{2+}$ in the $50 \mathrm{mM} \mathrm{Ca}^{2+}$ solution. A value of 0.8 was used for

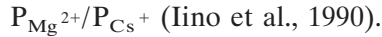

The membrane surface area of a neuron was estimated from the measurement of whole-cell capacitance. The whole-cell capacitance was measured as the capacitance compensation needed to cancel the capacitive transient during a $10 \mathrm{mV}$ voltage step in the whole-cell mode.

Single-cell RT-PCR and restriction analysis. After electrophysiological recording the cell content was aspirated into the patch pipette and expelled with the pipette solution $(4 \mu \mathrm{l})$ into the reverse transcription mix containing: $5 \times$ first-strand buffer $(2.5 \mu \mathrm{l}$; Life Technologies $)$, dithiothreitol ( $1 \mu \mathrm{l}$; Life Technologies), dNTPs (4 $\mu$ l of a $2.5 \mathrm{~mm}$ stock; Amersham Pharmacia Biotech, Piscataway, NJ), random hexamers $(1 \mu 1$ of a $2.5 \mu \mathrm{g} / \mu \mathrm{l}$ stock; Boehringer Mannheim, Indianapolis, IN), RNase inhibitor $(0.5 \mu \mathrm{l}$ or $20 \mathrm{U}$; Promega, Madison, WI), and reverse transcriptase (Life Technologies Superscript II; $0.5 \mu \mathrm{l}$ or $100 \mathrm{U}$ ) to a total of 13.5 $\mu 1$. This RT mix was incubated at $42^{\circ} \mathrm{C}$ for $45 \mathrm{~min}$, then at $99^{\circ} \mathrm{C}$ for $5 \mathrm{~min}$, and finally at $5^{\circ} \mathrm{C}$ for $5 \mathrm{~min}$ and then stored at $-20^{\circ} \mathrm{C}$ until PCR was done.

PCR for relative quantification of the four AMPA receptor subunits was performed using a protocol similar to that described by Lambolez et al. (1992), except that we used only 40 instead of 75 PCR cycles. Upstream ("up") and downstream ("lo") primers were used that amplify all AMPA receptor subunit sequences in parallel (Lambolez et al., 1992). Three introns are present in the GluR1-4 genes between these two primer positions, so that the cDNA amplification product cannot be confounded with gene amplification product. The entire RT reaction product was added to a PCR mix containing PCR buffer (Perkin-Elmer, Foster City, CA), 10 pmol of each primer, 0.05 mM dNTPs (Amersham Pharmacia Biotech), 2.5 U of Taq polymerase (Perkin-Elmer) and 1.125 $\mathrm{mM} \mathrm{MgCl}_{2}$ to a final volume of $100 \mu \mathrm{l}$. The PCR mix was put in a thin-walled reaction tube, covered with oil, and placed in the thermal 
cycler for five cycles of $94^{\circ} \mathrm{C}$ for $30 \mathrm{sec}, 45^{\circ} \mathrm{C}$ for $30 \mathrm{sec}$, ramp to $72^{\circ} \mathrm{C}$ over $1 \mathrm{~min} 10 \mathrm{sec}$, and $72^{\circ} \mathrm{C}$ for $1 \mathrm{~min}$, which were then followed by 35 cycles of $94^{\circ} \mathrm{C}$ for $30 \mathrm{sec}, 49^{\circ} \mathrm{C}$ for $30 \mathrm{sec}$, and $72^{\circ} \mathrm{C}$ for $1 \mathrm{~min}$. Extension was concluded with $72^{\circ} \mathrm{C}$ for 10 min. PCR product $(10 \mu \mathrm{l})$ was run on a $1.5 \%$ agarose gel stained with ethidium bromide, together with $10 \mathrm{ng}$ of an approximately $600 \mathrm{bp}$ fragment amplified from actin cDNA. Products of successful PCR reactions were ethanol-precipitated and resuspended in $\mathrm{H}_{2} \mathrm{O}$ for subsequent restriction digestion. PCR products of which the band on agarose gel was clearly weaker than the $10 \mathrm{ng}$ calibration band were not used for restriction analysis; this was the case for 4 of a total of 27 positive PCR results from single cells. PCR products from two cells were excluded because of unclear labeling of the PCR tubes. Two types of negative controls were taken during each electrophysiological session, subjected to RT-PCR, and run on agarose gels together with the cell samples. The first type of negative control consisted of patch pipette content after aspiration of bath solution into the pipette for $20 \mathrm{sec}$. The second type of negative control consisted of patch pipette content after forming a cell-attached seal without breaking into the whole-cell configuration. None of these negative controls $(n=36)$ produced a visible PCR band.

The precipitate of successful PCR reactions was digested overnight at $37^{\circ} \mathrm{C}$ with a mixture of four subunit-specific enzymes (Lambolez et al., 1992): BglI (for GluR1), Bsp1286I (for GluR2), Eco47III (for GluR3), and EcoRI (for GluR4). Digestion products were separated on 5\% polyacrylamide gels, treated with the fluorescent dye SYBR Green-1, and quantified by digital fluorimetric scanning (ImageQuant version 1.2; Molecular Dynamics, Sunnyvale, CA). All eight digestion fragments were well resolved, except for the upper fragments of GluR3 and GluR4, which partially overlapped. To correct for this, the total density of these two overlapping bands was divided proportionately to the relative densities of the lower, nonoverlapping bands for GluR3 and GluR4 (corrected for length difference). Fractions of the PCR product that remained uncut after restriction digestion always constituted $<5 \%$ of the total product.

The relative proportion of $\mathrm{Q} / \mathrm{R}$ site edited and unedited GluR2 was determined as follows. Bands of successful first-round PCR reactions were excised from the agarose gel, purified with the QIAquick gel extraction kit (Qiagen, Valencia, CA), and subjected to GluR2-specific, second-round PCR. This was performed in the same PCR mix given above with $1.5 \mathrm{mM} \mathrm{MgCl}_{2}$, using lo as downstream primer and a GluR2specific upstream primer, to amplify a GluR2 cDNA fragment of $634 \mathrm{bp}$. The sequence of this primer was 5'-ATGGAAGAGAAACACAAAGTAG-3'. The temperature profile of the second-round PCR was $94^{\circ} \mathrm{C}$ for $30 \mathrm{sec}, 55^{\circ} \mathrm{C}$ for $30 \mathrm{sec}$, and $72^{\circ} \mathrm{C}$ for $45 \mathrm{sec}(30 \mathrm{cycles})$, followed by $72^{\circ} \mathrm{C}$ for $10 \mathrm{~min}$. The second-round PCR product was ethanolprecipitated and resuspended in $\mathrm{H}_{2} \mathrm{O}$ for restriction analysis. Purity of the GluR2 product was verified for each sample by complete $(>99.5 \%)$ digestion with the GluR2-specific enzyme Bsp1286I. The 634 bp GluR2 sequence was digested with the restriction enzyme $T s e \mathrm{I}$ for $1 \mathrm{hr}$ at $65^{\circ} \mathrm{C}$. This enzyme cuts edited GluR2 at one site, yielding two fragments (444 and $190 \mathrm{bp}$ ), and cuts unedited GluR2 at an additional site, yielding three fragments $(444,106$, and $84 \mathrm{bp})$. The fragments were again quantified by digital fluorimetric scanning after separation on $5 \%$ polyacrylamide gels. The fraction of GluR2 that was edited at the $\mathrm{Q} / \mathrm{R}$ site was then determined by dividing the integrated density of the $190 \mathrm{bp}$ fragment by the sum of the integrated densities of the 190, 106, and 84 bp fragments. As a control in this assay, a 634 bp GluR1 sequence was also amplified using the same second-round PCR protocol as for GluR2, except that a GluR1specific upstream primer was used. The sequence of this primer was 5'-AGGGACGAGACCAGACAACCAG-3'. Purity of the GluR1 product was confirmed by complete digestion with the GluR1-specific enzyme $B g l$ I. TseI digestion of this (unedited) GluR1 fragment was predicted to produce three fragments $(444,106$, and $84 \mathrm{bp}$ ), analogous to the digestion pattern of the unedited version of GluR2.

We have previously demonstrated the validity of this RT-PCR protocol for the quantification of relative levels of AMPA receptor subunit mRNAs (Brorson et al., 1999). Additional control experiments were performed for the present study. RNA was transcribed from cDNA clones of the four AMPA receptor subunits (gifts from Dr. P. Seeburg, MaxPlanck-Institute for Medical Research, Heidelberg, Germany; and Dr. S. Heinemann, The Salk Institute, San Diego, CA). The RT-PCR protocol was applied to AMPA receptor subunit RNA mixtures of known composition, starting from amounts as little as $\sim 400$ RNA molecules, with reliable reproduction of the relative abundance of each subunit (Fig. 1).
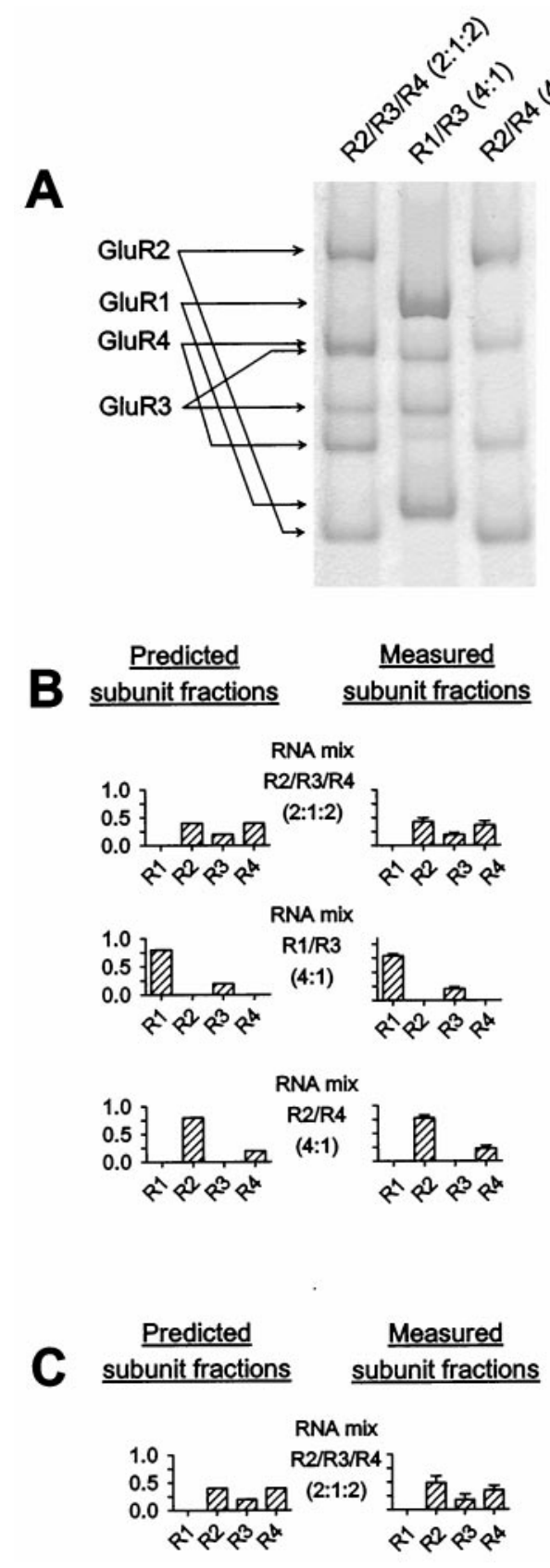

Figure 1. Validation of quantification of relative levels of AMPA receptor subunits. The RT-PCR protocol was applied to control RNA mixtures of known subunit composition to test whether subunit ratios were maintained during RT-PCR. RT-PCR products were digested simultaneously with all four subunit-specific restriction enzymes. Digestion products were visualized on $5 \%$ polyacrylamide gels by digital fluorimetric scanning. $A$, Restriction digestion products after RT-PCR amplification of three different AMPA receptor RNA control mixtures. Each mixture contained $\sim 0.004 \mathrm{fmol}(\sim 2.4$ million) copies. $B$, Quantification of fractional subunit content of control RNA mixtures after RT-PCR and restriction digestion. Predicted subunit compositions are shown at left, and the results of measurements starting from $0.004 \mathrm{fmol}$ of each control RNA mixture are shown at right $(n=5$ for each mix). $C$, For one of the control mixtures shown in $B$, relative quantification of subunit content by RT-PCR was also performed starting from very low $(\sim 400)$ RNA copies $(n=3)$.

Thus, these control experiments again confirmed the ability of this assay to quantify the fractional expression of AMPA receptor subunit mRNAs.

Data analysis. All numerical values given denote mean \pm SD. Error bars in the figures also indicate SD. 

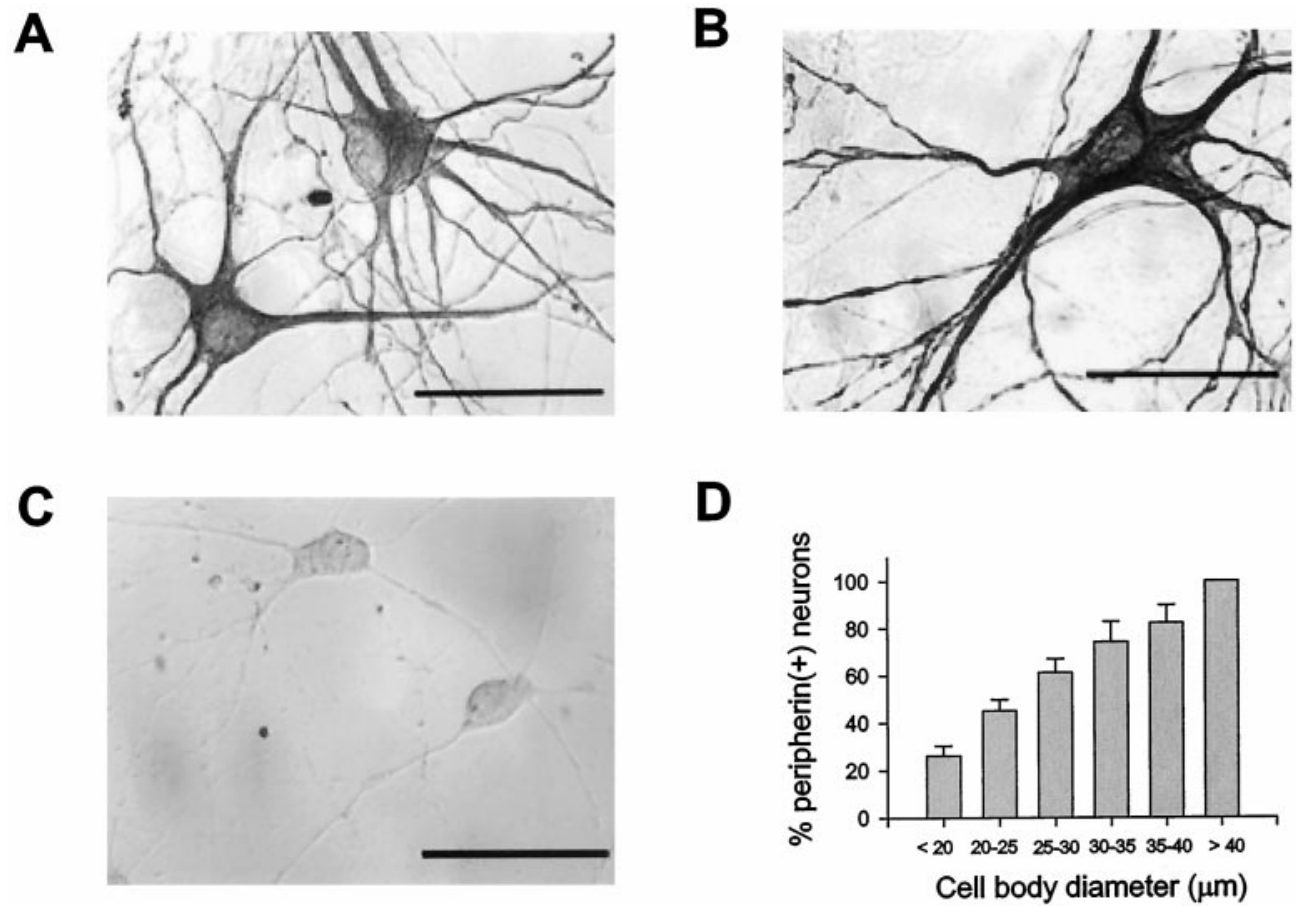

Figure 2. Immunostaining of cultures for the motoneuron markers peripherin and SMI-32. A, Peripherin staining of motoneuron-enriched culture on day 10 in vitro. $B$, SMI-32 staining of motoneuron-enriched culture on day 10 in vitro. $C$, Peripherin staining of dorsal horn culture on day 11 in vitro. $D$, Motoneuron-enriched cultures were stained for peripherin on days 10-12 in vitro, and the cell body diameters of peripherin $(+)$ and peripherin $(-)$ neurons were measured using a computer image analysis system $(n=3)$. In each experiment, at least 200 neurons were analyzed. The percentage of peripherin $(+)$ neurons was plotted against cell body diameter. Scale bars, $50 \mu \mathrm{m}$.

Statistical analysis was performed with SigmaStat (Jandel Scientific Software, San Rafael, CA). Statistical significance of differences was analyzed with two-tailed Student's $t$ test for comparison between two groups with equal variances, with Mann-Whitney rank sum test for comparison between two groups with unequal variances, and with oneway ANOVA and Student-Newman-Keuls test for comparison between more than two groups with equal variances.

The relationship between relative abundance of GluR2 mRNA and

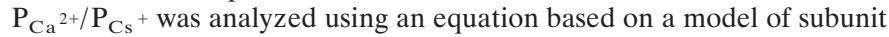
assembly proposed by Geiger et al. (1995):

$$
\mathrm{P}_{\text {tot }}=\left(\mathrm{P}_{\mathrm{I}}-\mathrm{P}_{\mathrm{II}}\right)(1-f)^{n}+\mathrm{P}_{\mathrm{II}},
$$

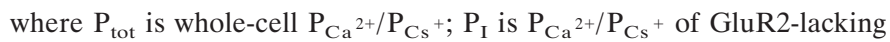
AMPA receptor channels; $\mathrm{P}_{\mathrm{II}}$ is $\mathrm{P}_{\mathrm{Ca}}{ }^{2+} / \mathrm{P}_{\mathrm{Cs}}{ }^{+}$of GluR2-containing receptors; $f$ is relative abundance of GluR2 mRNA; and $n=$ number of subunits per receptor. This equation was used to fit the data shown in Figure 7 by nonlinear regression, with $\mathrm{P}_{\mathrm{I}}$ and $\mathrm{P}_{\mathrm{II}}$ as the only free parameters. Significance of the correlation between relative abundance

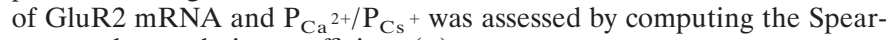
man rank correlation coefficient $\left(r_{\mathrm{s}}\right)$.

Materials. All restriction enzymes were purchased from New England Biolabs (Beverly, MA). AMPA was purchased from Research Biochemicals (Natick, MA), and MK-801 was purchased from Tocris Cookson (Ballwin, MO). SYBR Green-1 and tetrodotoxin were purchased from Molecular Probes (Eugene, OR). Other chemicals were obtained from Sigma.

\section{RESULTS}

\section{Cultures of motoneurons and dorsal horn neurons}

A highly motoneuron-enriched neuronal population was isolated from the ventral spinal cord of embryonic rats and was cultured on a pre-established feeder layer of spinal astrocytes. A large majority of these neurons were motoneurons, as shown by immunostaining with the motoneuron markers peripherin (Escurat et al., 1990) and SMI-32 (Carriedo et al., 1996). On days 10-14 in vitro, $84.7 \pm 6.5 \%$ of neurons were peripherin-positive, and
$81.6 \pm 4.7 \%$ of neurons were large $(>20 \mu \mathrm{m}$ in cell body diameter), SMI-32-positive neurons ( $n=3$ for each marker; Fig. $2 A, B)$. Motoneurons displayed a typical, highly differentiated morphology: a large, multipolar cell body, a prominent nucleus with a conspicuous nucleolus, and several thick neurites. Size of the neuronal cell body clearly correlated with the probability of staining with motoneuron markers (Fig. 2D). Neurons with cell bodies $>40 \mu \mathrm{m}$ were invariably peripherin $(+)$ and SMI-32(+).

Dissociated neurons from the dorsal spinal cord of embryonic rats were also grown on pre-established spinal astrocytic feeder layers in the same culture conditions as motoneurons. Only $3.4 \pm$ $1.8 \%$ of neurons in dorsal horn cultures were peripherin $(+)(n=$ 3 on days $10-14$ in vitro; Fig. 2C).

\section{Vulnerability of motoneurons and dorsal horn neurons to AMPA receptor agonists}

The vulnerability of motoneurons and dorsal horn neurons to prolonged AMPA receptor overactivation was studied by exposing motoneuron cultures and dorsal horn cultures for $24 \mathrm{hr}$ to the AMPA receptor agonists AMPA (30 $\mu \mathrm{M})$ and KA (20 and 100 $\mu \mathrm{M})$. As shown in Figure 3, motoneurons were substantially more vulnerable to each of these prolonged treatments than were dorsal horn neurons. This finding is in agreement with data from other in vitro models (Rothstein et al., 1993; Carriedo et al., 1996; Bar-Peled et al., 1999).

\section{Electrophysiological measurements of AMPA receptor $\mathrm{Ca}^{2+}$ permeability in motoneurons and dorsal horn neurons}

For electrophysiological recordings from the motoneuronenriched cultures, neurons with cell bodies $>40 \mu \mathrm{m}$ in diameter were selected, because neurons in this size category were invari- 


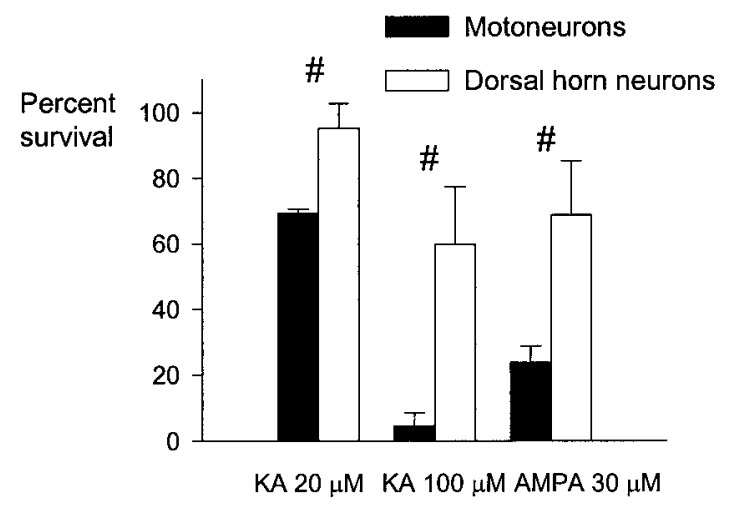

Figure 3. Vulnerability of motoneurons and dorsal horn neurons to AMPA receptor agonists. Motoneurons and dorsal horn neurons were exposed to KA and AMPA for $24 \mathrm{hr}(n=3-4$ for each condition). MK-801 $(10 \mu \mathrm{M})$ was added during all agonists exposures. ${ }^{\#}$ Significant difference $(p<0.05)$ between motoneurons and dorsal horn neurons by ANOVA and Student-Newman-Keuls test.

ably stained with the motoneuron markers peripherin and SMI-32 (Fig. 2D). To determine the relative $\mathrm{Ca}^{2+}$ permeability of AMPA receptors in motoneurons, we measured reversal potentials of the $I-V$ relationships of the responses to $100 \mu \mathrm{M} \mathrm{KA}$ in whole-cell voltage-clamp experiments. $I-V$ relationships were recorded in a $\mathrm{Na}^{+}$-free, sucrose-based extracellular solution in which the only cation was $\mathrm{Ca}^{2+}$. MK-801 (10 $\left.\mu \mathrm{M}\right), \mathrm{Cd}^{2+}(100$ $\mu \mathrm{M})$, and tetrodotoxin $(0.5 \mu \mathrm{M})$ were added to the extracellular solution to block NMDA receptors, voltage-gated $\mathrm{Ca}^{2+}$ channels, and $\mathrm{Na}^{+}$channels, respectively. To detect a positive shift in reversal potential with increase in the external $\mathrm{Ca}^{2+}$ concentration, consistent with permeability to $\mathrm{Ca}^{2+}, I-V$ curves were recorded in each motoneuron in 15 and $50 \mathrm{~mm}$ extracellular $\left[\mathrm{Ca}^{2+}\right]\left(\left[\mathrm{Ca}^{2+}\right]_{\mathrm{e}}\right)$.

An example of $I-V$ curves recorded from a motoneuron in 15 and $50 \mathrm{~mm}\left[\mathrm{Ca}^{2+}\right]_{\mathrm{e}}$ is shown in Figure $4 A$. Under our experimental conditions, $I-V$ curves from motoneurons were slightly outwardly rectifying. At the initial holding potential of $-100 \mathrm{mV}$, KA evoked nondesensitizing inward currents in all motoneurons studied ( $n=25$; Fig. $4 A$ ). This inward current is likely to be carried by $\mathrm{Ca}^{2+}$, because this was the only cation in the extracellular solution. KA can activate AMPA receptors and KA receptors (Partin et al., 1993), and both types of receptors can potentially flux $\mathrm{Ca}^{2+}$ (Egebjerg and Heinemann, 1993). We determined which class of receptors was responsible for the KAinduced inward $\mathrm{Ca}^{2+}$ currents in motoneurons using the selective AMPA receptor antagonist GYKI 53655 (Bleakman et al., 1996). GYKI $53655(50 \mu \mathrm{M})$ completely blocked KA-evoked inward currents ( $n=4$ motoneurons; data not shown), indicating that these currents were mediated by AMPA receptors. Thus, these observations qualitatively demonstrate the existence of AMPA receptors with measurable $\mathrm{Ca}^{2+}$ permeability in motoneurons.

Reversal potentials in $15 \mathrm{~mm}\left[\mathrm{Ca}^{2+}\right]_{\mathrm{e}}$ were related to relative

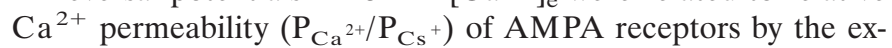
tended constant field equation (Mayer and Westbrook, 1987). The average reversal potential in $15 \mathrm{~mm}\left[\mathrm{Ca}^{2+}\right]_{\mathrm{e}}$ was $-61.1 \pm$ $17.0 \mathrm{mV}(n=25$; range, -97.2 to $-35.2 \mathrm{mV})$, yielding an average

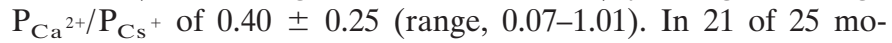
toneurons $(84 \%), \mathrm{P}_{\mathrm{Ca}^{2+}} / \mathrm{P}_{\mathrm{Cs}^{+}}$had a value between 0.15 and 0.8 . In three motoneurons, $\mathrm{P}_{\mathrm{Ca}^{2+}} / \mathrm{P}_{\mathrm{Cs}}+$ was very low (0.05-0.1), and one motoneuron had a $\mathrm{P}_{\mathrm{Ca}^{2+}} / \mathrm{P}_{\mathrm{Cs}}$ of 1.01 . There was a substan-
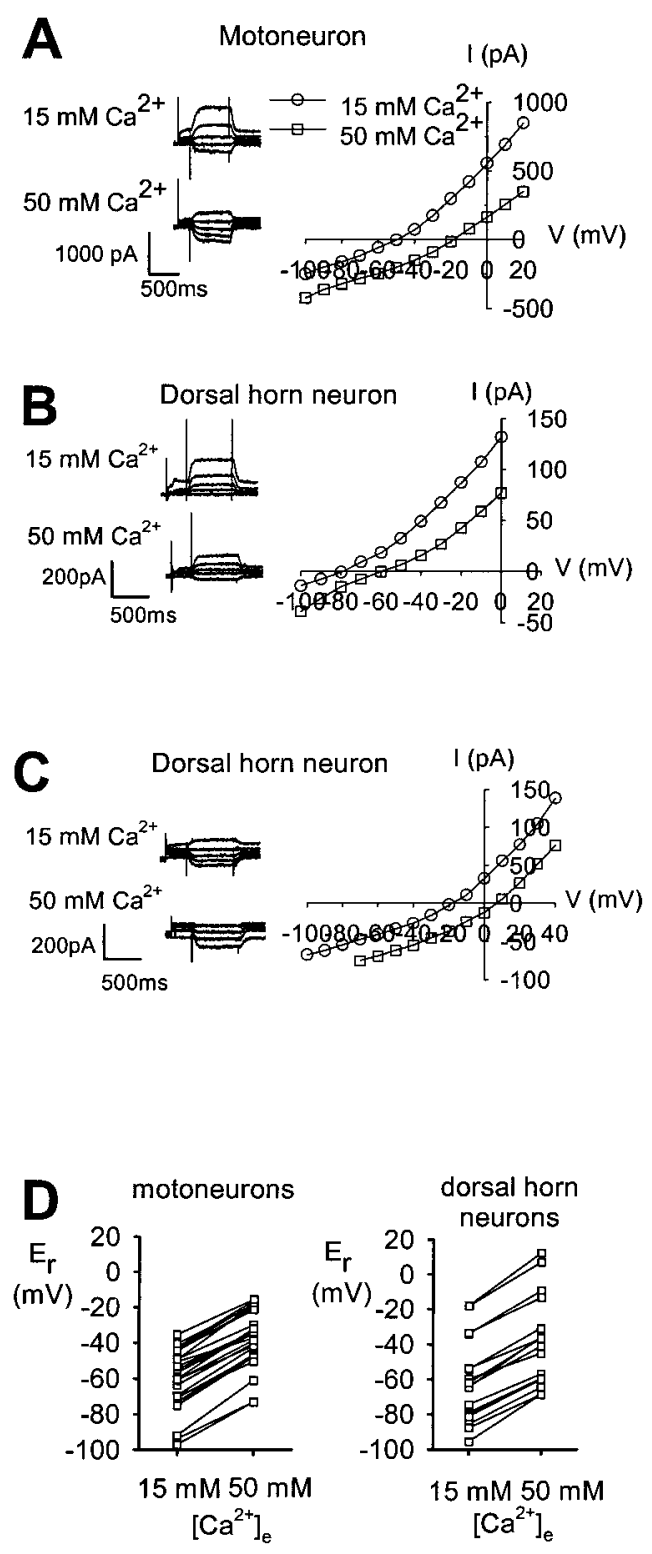

Figure 4. Reversal potential measurements in motoneurons and dorsal horn neurons. $A-\mathrm{C}$, Whole-cell currents evoked by $100 \mu \mathrm{M} \mathrm{KA}$ in Na ${ }^{+}$free solutions containing 15 and $50 \mathrm{mM} \mathrm{Ca}^{2+}$, at holding potentials ranging from -100 to $+40 \mathrm{mV}$ and resulting leak-subtracted $I-V$ relationships. $A, I-V$ relationship in a motoneuron. Insets show current traces at $-80,-60,-40,-20$, and $0 \mathrm{mV}$. In this cell, a whole-cell capacitance was measured of $100 \mathrm{pF} . B, I-V$ relationship in a dorsal horn neuron with low relative $\mathrm{Ca}^{2+}$ permeability. Insets show current traces at $-80,-60$, $-40,-20$, and $0 \mathrm{mV}$. In this cell, a whole-cell capacitance of $39 \mathrm{pF}$ was measured. $C, I-V$ relationship in a dorsal horn neuron with high relative $\mathrm{Ca}^{2+}$ permeability. Insets show current traces at $-80,-60,-40,-20$, and $0 \mathrm{mV}$ for $15 \mathrm{mM} \mathrm{Ca}^{2+}$ and at $-60,-40,-20$, and $0 \mathrm{mV}$ for $50 \mathrm{mM} \mathrm{Ca}^{2+}$. This cell had a whole-cell capacitance of $44 \mathrm{pF}$. D, Summary of reversal potentials $\left(E_{\mathrm{r}}\right)$ of $\mathrm{KA}$-induced currents in 15 and $50 \mathrm{mM} \mathrm{Ca}{ }^{2+}$ for all motoneurons (left; $n=25)$ and dorsal horn neurons (right; $n=18$ ).

tial positive shift in reversal potential in all motoneurons with increase of the $\left[\mathrm{Ca}^{2+}\right]_{\mathrm{e}}$ from 15 to $50 \mathrm{~mm}$ (Fig. $4 D$ ). The average reversal potential in $50 \mathrm{~mm}\left[\mathrm{Ca}^{2+}\right]_{\mathrm{e}}$ was $-37.6 \pm 16.3 \mathrm{mV}(n=$ 25 ; range, -73.1 to $-15.5 \mathrm{mV})$.

$I-V$ relationships of KA-evoked currents in 15 and $50 \mathrm{~mm}$ $\left[\mathrm{Ca}^{2+}\right]_{\mathrm{e}}$ were also recorded from dorsal horn neurons (Fig. $4 B-$ 
$D)$. I- $V$ curves from dorsal horn neurons were slightly outwardly rectifying. As in motoneurons, KA induced nondesensitizing inward currents in all dorsal horn neurons $(n=18)$ at the initial holding potential of $-100 \mathrm{mV}$. Reversal potentials varied over a wider range in dorsal horn neurons than in motoneurons (Fig. $4 B-D)$. The average reversal potential in $\left.15 \mathrm{~mm} \mathrm{Ca}^{2+}\right]_{\mathrm{e}}$ was $-61.7 \pm 23.1 \mathrm{mV}(n=18$; range, -95.5 to $-17.8 \mathrm{mV})$. The average $\mathrm{P}_{\mathrm{Ca}^{2+}} / \mathrm{P}_{\mathrm{Cs}}+$ ratio, calculated from these reversal potential values, was $0.57 \pm 0.74(n=18$; range, $0.08-2.45)$. As in motoneurons, there was a considerable positive shift in reversal potential in all dorsal horn neurons with increase of $\left[\mathrm{Ca}^{2+}\right]_{\mathrm{e}}$ from 15 to $50 \mathrm{~mm}$ (Fig. $4 D$ ). The reversal potential in $50 \mathrm{~mm}\left[\mathrm{Ca}^{2+}\right]_{\mathrm{e}}$ was $-39.5 \pm 24.8 \mathrm{mV}(n=18$; range, -68.6 to $+12.4 \mathrm{mV})$. There was no significant difference between dorsal horn neurons and motoneurons with respect to the mean reversal potentials in 15 and $50 \mathrm{~mm}\left[\mathrm{Ca}^{2+}\right]_{\mathrm{e}}$ or $\mathrm{P}_{\mathrm{Ca}^{2+}} / \mathrm{P}_{\mathrm{Cs}^{+}}$.

Motoneurons are larger cells than dorsal horn neurons. It was therefore not surprising that the amplitudes of KA-evoked inward and outward currents were consistently higher in motoneurons than in dorsal horn neurons (Fig. 4A-C). Interestingly, however, the difference in current amplitudes between both sets of neurons was considerably larger than would be expected from the difference in membrane surface area, as estimated from the measurements of whole-cell capacitance. Cell capacitance typically ranged from 70 to $110 \mathrm{pF}$ in motoneurons and from 20 to 50 $\mathrm{pF}$ in dorsal horn neurons. Although this was not the primary purpose of these experiments, we calculated density of inward current by dividing inward current (in $\left.15 \mathrm{mM}^{\mathrm{C}} \mathrm{Ca}^{2+}\right]_{\mathrm{e}}$ at a membrane potential $20 \mathrm{mV}$ more negative than the reversal potential) by the whole-cell capacitance. Inward current density of AMPA receptors in motoneurons was nearly threefold that in dorsal horn neurons: inward current density was $-1.30 \pm 0.74$ $\mathrm{pA} / \mathrm{pF}$ in motoneurons ( $n=17$; range, -0.48 to $-3.37 \mathrm{pA} / \mathrm{pF}$ ) and $-0.45 \pm 0.20 \mathrm{pA} / \mathrm{pF}$ in dorsal horn neurons $(n=17$; range, -0.19 to $-0.88 \mathrm{pA} / \mathrm{pF})$. This difference was highly significant $(p<0.00001)$. Outward current density, primarily reflecting outward permeation of the monovalent ion $\mathrm{Cs}^{+}$, was calculated analogously, using outward currents at a membrane potential 20 $\mathrm{mV}$ more positive than the reversal potential. Outward current density was also considerably higher $(p<0.00001)$ in motoneurons $(1.71 \pm 0.76 \mathrm{pA} / \mathrm{pF}$; range, $0.76-3.20 \mathrm{pA} / \mathrm{pF} ; n=18)$ than in dorsal horn neurons $(0.54 \pm 0.21 \mathrm{pA} / \mathrm{pF}$; range, $0.32-0.92 \mathrm{pA} / \mathrm{pF}$; $n=18)$.

\section{AMPA receptor subunit expression patterns in motoneurons and dorsal horn neurons}

Single-cell RT-PCR amplification of AMPA receptor subunit mRNA after whole-cell patch-clamp studies was successful in 10 of 18 attempts in motoneurons and in 11 of 16 attempts in dorsal horn neurons.

As illustrated in Figure 5, all motoneurons expressed substantial relative amounts of GluR2 (39 $\pm 11 \%$; range, $25-59 \%)$, GluR1 (27 \pm 15\%; range, $13-63 \%)$, and GluR4 (25 $\pm 11 \%$; range, $9-42 \%$ ). GluR3 was expressed at a considerable level in 5 of 10 motoneurons (range, 15-23\%) and was undetectable in the other 5 .

Dorsal horn neurons showed a much more variable AMPA receptor subunit expression pattern, reflecting the heterogeneous makeup of this cell group (Fig. 5). All dorsal horn neurons expressed GluR2, in a relative amount ranging from 6 to $85 \%$. There was no significant difference in the average fraction of GluR2 between motoneurons and dorsal horn neurons. The rel-

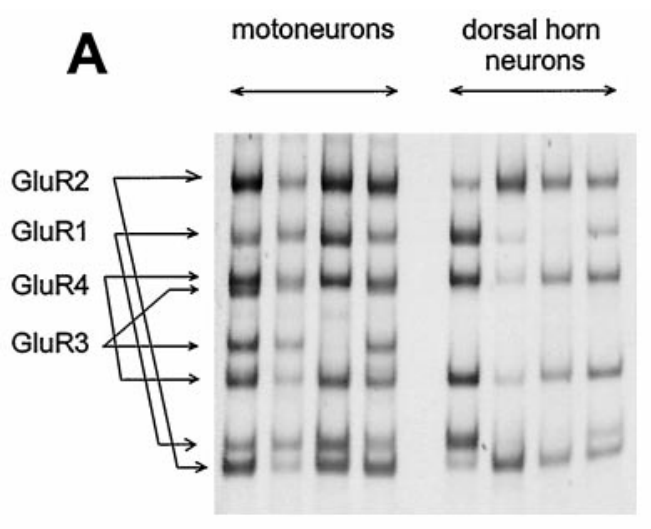

B motoneurons dorsal horn neurons

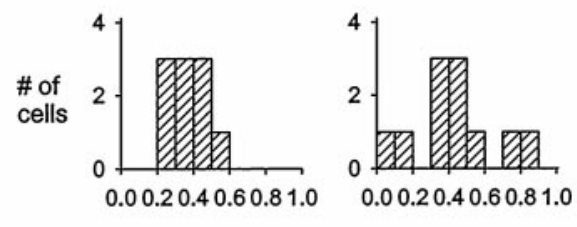

Fraction GluR-2

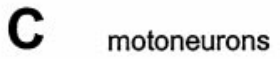

dorsal horn neurons
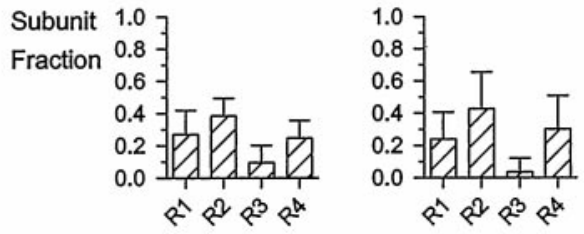

Figure 5. AMPA receptor subunit expression patterns in motoneurons and dorsal horn neurons. A, Fractional AMPA receptor subunit expression pattern in four motoneurons (left) and four dorsal horn neurons $($ right $)$. PCR products from single cells were digested with a mix of four subunit-specific enzymes and separated on $5 \%$ polyacrylamide gels. $B$, Histograms summarizing distributions of fractional GluR2 expression (expressed as percentage of total AMPA receptor subunit mRNA) in motoneurons (left; $n=10)$ and dorsal horn neurons (right; $n=11)$. $C$, Summary of fractional subunit expression in motoneurons $(l e f t ; n=10)$ and dorsal horn neurons (right; $n=11$ ).

ative abundance of GluR1 and GluR4 in dorsal horn neurons varied from 0 to $46 \%$ and from 0 to $50 \%$, respectively. GluR3 was detected in only 2 of 11 dorsal horn neurons.

The GluR2 subunit reduces the relative $\mathrm{Ca}^{2+}$ permeability of AMPA receptors because of the presence of an arginine at a critical position (the "Q/R site") in its pore-forming segment (Hume et al., 1991; Burnashev et al., 1992). This arginine codon is created at the pre-mRNA stage by RNA editing (Sommer et al., 1991). In rodent brain, GluR2 has been shown to be almost completely edited at the Q/R site (Sommer et al., 1991; Burnashev et al., 1992). However, no data are available about the Q/R site editing status of GluR2 in the mammalian spinal cord. Incomplete editing of GluR2 in spinal neurons might produce a deviation from the relative $\mathrm{Ca}^{2+}$ permeability predicted on the basis of their relative expression of GluR2. We therefore determined whether single motoneurons and dorsal horn neurons expressed any GluR2 in its Q/R site unedited version. As illus- 


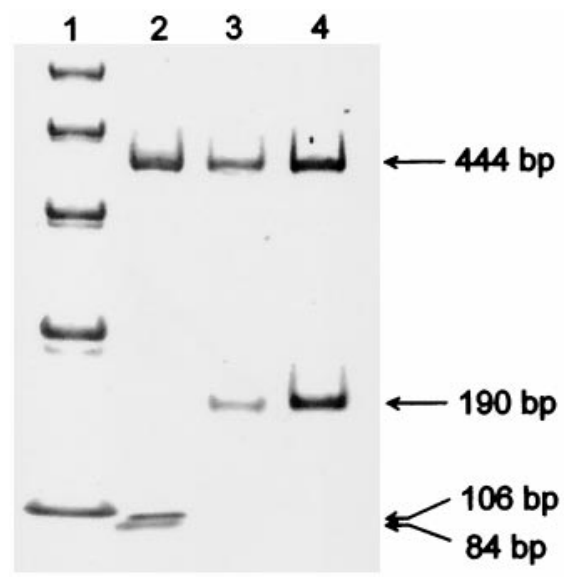

Figure 6. $\mathrm{Q} / \mathrm{R}$ site editing in motoneurons and dorsal horn neurons. Polyacrylamide (5\%) gel showing GluR1 and GluR2 sequences digested with TseI. Lane 1, 123 bp molecular weight marker (lowest band corresponds to $123 \mathrm{bp}$ ). Lane 2, TseI digestion of GluR1 fragment amplified from a motoneuron. Lane 3, TseI digestion of GluR2 fragment amplified from a motoneuron. Lane 4, TseI digestion of GluR2 fragment amplified from a dorsal horn neuron. As described in Materials and Methods, the digestion patterns in the samples shown are consistent with complete editing of GluR2 at the $Q / R$ site and with absence of $Q / R$ site editing of GluR1.

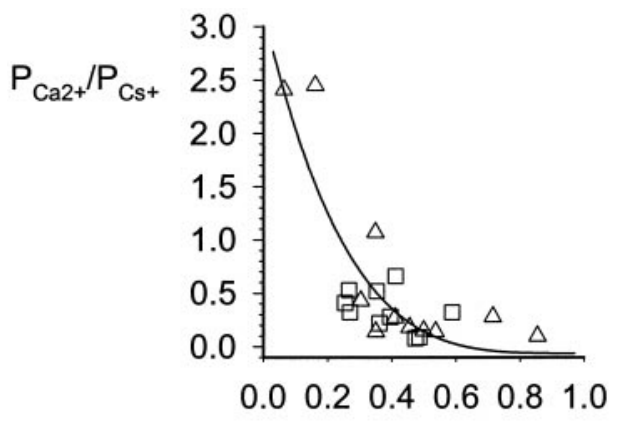

Fraction GluR-2

Figure 7. Relation between AMPA receptor relative $\mathrm{Ca}^{2+}$ permeability and relative abundance of GluR2 mRNA. The plot shows relative $\mathrm{Ca}^{2+}$

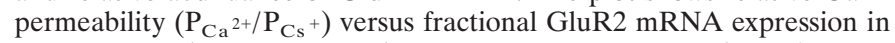
motoneurons (squares; $n=10$ ) and dorsal horn neurons (triangles; $n=$ 11). The curve represents least-squares fit of the relationship between the two parameters by nonlinear regression using a model similar to that described by Geiger et al. (1995).

trated in Figure 6, GluR2 was completely edited at the Q/R site in 9 of 10 motoneurons and in 9 of 11 dorsal horn neurons. In one motoneuron and two dorsal horn neurons, unedited GluR2 was detected at very low levels $(3,5$, and $5 \%$ of total GluR2 mRNA, respectively). As expected, GluR1 from motoneurons was completely unedited at the Q/R site (Fig. 6).

\section{Relationship between AMPA receptor relative $\mathrm{Ca}^{2+}$ permeability and relative abundance of GluR2 mRNA}

In 21 cells (10 motoneurons and 11 dorsal horn neurons), both

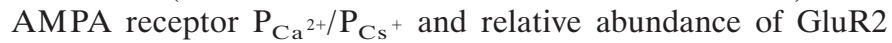
mRNA were determined, allowing a comparison of both parameters on a cell-by-cell basis (Fig. 7). There was a strong negative correlation between $\mathrm{P}_{\mathrm{Ca}^{2+}} / \mathrm{P}_{\mathrm{Cs}}{ }^{+}$and the relative abundance of GluR2 mRNA $\left(r_{\mathrm{s}}=-0.83 ; p<0.005\right)$. The relationship between these parameters was fit by nonlinear regression using an equa- tion based on a model similar to that proposed by Geiger et al. (1995). This model makes four assumptions. The first assumption is that channels containing one or more GluR2 subunits have a uniformly low $\mathrm{P}_{\mathrm{Ca}^{2+}} / \mathrm{P}_{\mathrm{Cs}^{+}}$, whereas channels lacking GluR2 have a uniformly high $\mathrm{P}_{\mathrm{Ca}^{2+}} / \mathrm{P}_{\mathrm{Cs}^{+}}$. Second, the relative abundances of GluR2 mRNA and protein are the same. Third, all subunits assemble freely with each other with the same probability. The final assumption is that the receptor is a tetramer (Rosenmund et al., 1998). This model predicts the fraction of highly $\mathrm{Ca}^{2+}$ permeable (GluR2-lacking) AMPA receptors in a cell to be (1 $f)^{4}$, with $f$ representing the relative abundance of GluR2 mRNA, so that, for example, in an average motoneuron with a fractional GluR2 mRNA expression of 0.39, approximately one of seven AMPA receptors would be highly $\mathrm{Ca}^{2+}$-permeable. The data were well fit by this model ( $r=0.85 ; p<0.0001)$, although AMPA

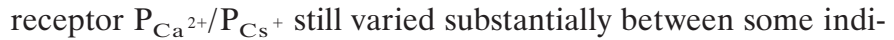
vidual cells with similar relative levels of GluR2 mRNA (especially with fractions of GluR2 mRNA in the range of $25-40 \%$ of total AMPA receptor mRNA). A model assuming a pentameric channel structure also produced a highly significant fit $(r=0.87$; $p<0.0001$; data not shown).

\section{DISCUSSION}

\section{Relative $\mathrm{Ca}^{2+}$ permeability of AMPA receptors in motoneurons and dorsal horn neurons}

The first aim of this study was to quantify the relative $\mathrm{Ca}^{2+}$ permeability of AMPA receptors in spinal motoneurons and to compare this parameter between motoneurons and dorsal horn neurons.

We found an average AMPA receptor $\mathrm{P}_{\mathrm{Ca}^{2+}} / \mathrm{P}_{\mathrm{Cs}^{+}}$of 0.4 in spinal motoneurons. Although caution is required when making direct comparisons between the $\mathrm{P}_{\mathrm{Ca}^{2+}} / \mathrm{P}_{\text {monovalent }}$ values reported by different groups because of differences in experimental conditions and calculation factors, the $\mathrm{P}_{\mathrm{Ca}^{2+}} / \mathrm{P}_{\text {monovalent }}$ values of motoneurons are clearly "intermediate" between the high and low

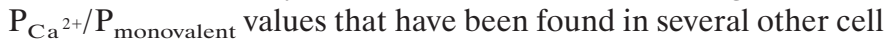
types. Classical examples of cell types with high AMPA receptor $\mathrm{P}_{\mathrm{Ca}^{2+}} / \mathrm{P}_{\text {monovalent }}$ values $\left(\mathrm{P}_{\left.\mathrm{Ca}^{2+} / \mathrm{P}_{\text {monovalent }}>2\right) \text { are hippocampal }}\right.$ type II neurons (Iino et al., 1990) and Bergman glia (Geiger et al., 1995); these cell types express no or virtually no GluR2 mRNA (Bochet et al., 1994; Geiger et al., 1995) and therefore probably express a rather uniform population of GluR2-less, highly $\mathrm{Ca}^{2+}$ permeable AMPA receptors. At the other end of the spectrum, several types of neurons are known to have very low $\mathrm{P}_{\mathrm{Ca}^{2+}}$ $\mathrm{P}_{\text {monovalent }}$ values, e.g., hippocampal type I neurons (Iino et al., 1990) and neocortical layer V pyramidal neurons (Jonas et al., 1994; Geiger et al., 1995); these cell types express a high relative abundance of GluR2 mRNA and are therefore likely to possess a population of predominantly GluR2-containing AMPA receptors (Bochet et al., 1994; Jonas et al., 1994; Geiger et al., 1995). Intermediate $\mathrm{P}_{\mathrm{Ca}^{2+}} / \mathrm{P}_{\text {monovalent }}$ values of AMPA receptors, similar to those of motoneurons, have previously been reported in, e.g., type III hippocampal neurons (Iino et al., 1994; Lerma et al., 1994) and neocortical layer IV nonpyramidal neurons (Jonas et al., 1994; Geiger et al., 1995). The most plausible interpretation of such intermediate $\mathrm{P}_{\mathrm{Ca}^{2+}} / \mathrm{P}_{\text {monovalent }}$ values is that they result from the presence of a mixed population ("mosaic") of $\mathrm{Ca}^{2+}$ permeable and -impermeable AMPA receptors in these cell types (Jonas and Burnashev, 1995). It is interesting to note that the AMPA receptor $\mathrm{P}_{\mathrm{Ca}^{2+}} / \mathrm{P}_{\text {monovalent }}$ of spinal motoneurons is considerably higher than that of large principal neurons in other neuronal circuitries, e.g., cerebellar Purkinje neurons (Brorson et 
al., 1999) and hippocampal and neocortical pyramidal neurons (Jonas et al., 1994; Geiger et al., 1995).

The $\mathrm{P}_{\mathrm{Ca}^{2+}} / \mathrm{P}_{\mathrm{Cs}^{+}}$values we measured in dorsal horn neurons were more widely distributed than in motoneurons. This was not unexpected given the heterogeneous cellular composition of the dorsal horn. The mean and distribution of the $\mathrm{P}_{\mathrm{Ca}^{2+}} / \mathrm{P}_{\mathrm{Cs}^{+}}$values in dorsal horn neurons are consistent with results published by Goldstein et al. (1995). Our results confirm their finding that $>95 \%$ of dorsal horn neurons express electrophysiologically detectable levels of $\mathrm{Ca}^{2+}$-permeable AMPA receptors, and that a subset of dorsal horn neurons ( $\sim 10 \%$ of our sample) have very high $(>2.0) \mathrm{P}_{\mathrm{Ca}^{2+}} / \mathrm{P}_{\mathrm{Cs}}+$ values.

There was no clear difference in mean AMPA receptor $\mathrm{P}_{\mathrm{Ca}^{2+}}$ $\mathrm{P}_{\mathrm{Cs}}+$ between motoneurons and dorsal horn neurons. This may seem surprising in light of previous studies using KA-activated $\mathrm{Co}^{2+}$ uptake. KA-activated $\mathrm{Co}^{2+}$ uptake is a qualitative staining technique that reflects the intracellular $\mathrm{Co}^{2+}$ concentration after KA-induced $\mathrm{Co}^{2+}$ entry through AMPA receptors (Pruss et al., 1991). Labeling of a neuron with this technique is considered evidence for the presence of $\mathrm{Co}^{2+}$-permeable (and therefore presumably also $\mathrm{Ca}^{2+}$-permeable) AMPA receptors in its membrane. Between 60 and $80 \%$ of cultured spinal motoneurons are labeled with this technique (Carriedo et al., 1996; Vandenberghe et al., 1998a; Bar-Peled et al., 1999), compared with a lower percentage of labeled neurons in dissociated total spinal cord cultures (30-45\%; Yin et al., 1995; Bar-Peled et al., 1999) and dissociated dorsal horn cultures ( $50 \%$; Albuquerque et al., 1999). To understand this seeming discrepancy between the

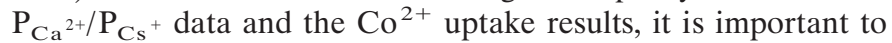
realize that these techniques measure different aspects of AMPA receptor divalent cation permeability. KA-activated $\mathrm{Co}^{2+}$ uptake staining can be influenced by any factor that affects the magnitude of AMPA receptor-mediated $\mathrm{Co}^{2+}$ influx and the resulting intracellular and subcellular $\mathrm{Co}^{2+}$ concentrations. AMPA receptor $\mathrm{P}_{\text {divalent }} / \mathrm{P}_{\text {monovalent }}$ is only one of those factors; other factors include, for example, density, single-channel conductance and subcellular distribution of AMPA receptors, and cell volume and architecture, all of which may differ between neuronal cell types. The difference in KA-activated $\mathrm{Co}^{2+}$ uptake between motoneurons and dorsal horn neurons, despite similar mean AMPA receptor $\mathrm{P}_{\mathrm{Ca}^{2+}} / \mathrm{P}_{\mathrm{Cs}^{+}}$, could therefore be attributable to other factors, such as a difference in AMPA receptor density between both populations. In keeping with this idea, we found an approximately threefold larger AMPA receptor current density in motoneurons than in dorsal horn neurons. This suggests that motoneurons express AMPA receptors with considerably higher density and/or single-channel conductance and/or open probability than do dorsal horn neurons.

\section{Relative abundance of GluR2 in motoneurons and dorsal horn neurons}

The second aim of this study was to quantify the expression of GluR2 relative to the other AMPA receptor subunits in spinal motoneurons and to compare this parameter between motoneurons and dorsal horn neurons.

Because it is technically impossible to quantify the relative abundance of GluR2 protein in single cells, we used a single-cell RT-PCR method to provide a relative quantification of GluR2 at the mRNA level. All motoneurons expressed substantial relative amounts of GluR2, with an average value of $\sim 40 \%$ of total AMPA receptor subunit mRNA. This result is in agreement with previous qualitative evidence of GluR2 mRNA and protein ex- pression in rat and human spinal motoneurons (Furuyama et al., 1993; Tölle et al., 1993; Pellegrini-Giampietro et al., 1994; Jakowec et al., 1995; Tomiyama et al., 1996; Virgo et al., 1996; Petralia et al., 1997; Temkin et al., 1997; Morrison et al., 1998; Vandenberghe et al., 1998a; Grossman et al., 1999), although in two studies an absence of GluR2 in spinal motoneurons was described (Williams et al., 1997; Bar-Peled et al., 1999). In the present study, the moderate fractional expression of GluR2 in motoneurons was consistent with the intermediate relative $\mathrm{Ca}^{2+}$ permeability of their AMPA receptors (Geiger et al., 1995). The relative abundance of GluR2 mRNA varied much more widely in dorsal horn neurons than in motoneurons, but the mean values did not differ significantly between the two cell groups.

At least $99 \%$ of GluR2 mRNA undergoes Q/R site editing in embryonic, neonatal, and adult rat brain (Burnashev et al., 1992). Whether Q/R site editing of GluR2 also occurs in the mammalian spinal cord has never been investigated. We found GluR2 to be virtually completely edited at the $\mathrm{Q} / \mathrm{R}$ site in motoneurons and dorsal horn neurons. Thus, there does not appear to be a major difference in the degree of $\mathrm{Q} / \mathrm{R}$ site editing of GluR2 between brain and spinal cord.

We found a strong negative correlation between whole-cell AMPA receptor $\mathrm{P}_{\mathrm{Ca}^{2+}} / \mathrm{P}_{\mathrm{Cs}}{ }^{+}$and relative abundance of GluR2 mRNA in individual cells. In addition, the data were well fit by a model that predicts $\mathrm{P}_{\mathrm{Ca}^{2+}} / \mathrm{P}_{\mathrm{Cs}}+$ from the relative level of GluR2 mRNA. This is in agreement with previous work (Geiger et al., 1995; Washburn et al., 1997; Brorson et al., 1999) and indicates that AMPA receptor $\mathrm{P}_{\mathrm{Ca}^{2+}} / \mathrm{P}_{\mathrm{Cs}}+$ may be determined primarily by the relative level of GluR2 transcription. However, considerable variations in AMPA receptor $\mathrm{P}_{\mathrm{Ca}^{2+}} / \mathrm{P}_{\mathrm{Cs}^{+}}$were still found between some individual cells with similar, moderate GluR2 expression levels. This may indicate that post-transcriptional regulatory mechanisms are also involved in fine tuning whole-cell relative $\mathrm{Ca}^{2+}$ permeability of native AMPA receptors.

\section{Implications for selective motoneuron vulnerability}

The final aim of this study was to determine whether the relative $\mathrm{Ca}^{2+}$ permeability of AMPA receptors and the relative abundance of GluR2 could account for the selective vulnerability of spinal motoneurons to AMPA receptor agonists.

Our finding that spinal motoneurons are considerably more vulnerable than dorsal horn neurons to prolonged AMPA receptor overactivation confirms earlier findings in vivo (Hugon et al., 1989; Ikonomidou et al., 1996) and in organotypic (Rothstein et al., 1993) and dissociated (Carriedo et al., 1996; Bar-Peled et al., 1999) spinal cord cultures. The selective vulnerability of motoneurons to AMPA receptor agonists thus appears to be a robust, model-independent phenomenon. The present study demonstrates that this phenomenon cannot be explained by wholecell relative $\mathrm{Ca}^{2+}$ permeability of AMPA receptors or whole-cell relative GluR2 abundance, because these two parameters do not clearly differ between motoneurons and other spinal neurons.

This conclusion does not rule out a role for $\mathrm{Ca}^{2+}$-permeable AMPA receptors in selective motoneuron vulnerability. As discussed above, the magnitude of AMPA receptor-mediated $\mathrm{Ca}^{2+}$ influx and the resulting changes in intracellular $\mathrm{Ca}^{2+}$ concentration are determined not only by AMPA receptor $\mathrm{P}_{\mathrm{Ca}^{2+}} / \mathrm{P}_{\text {monovalent }}$ but also by many other factors such as density, desensitization (Brorson et al., 1995), and subcellular distribution of AMPA receptors, and $\mathrm{Ca}^{2+}$ buffering mechanisms. Any of these factors may differ between motoneurons and other spinal neurons and render motoneurons selectively vulnerable to AMPA receptor- 
mediated $\mathrm{Ca}^{2+}$ influx. Finally, it is important to emphasize that this study was performed on motoneurons from healthy animals that do not develop motoneuron disease. It is conceivable that the molecular and functional properties of AMPA receptors in motoneurons may be altered in certain disease states. This is illustrated by a recent transgenic mouse study (Feldmeyer et al., 1999; Kolhekar et al., 1998). A mouse was generated, which, in addition to both endogenous GluR2 alleles, carries multiple copies of a GluR2(N) minigene encoding a GluR2 subunit with asparagine at the $\mathrm{Q} / \mathrm{Rsite}$. AMPA receptors incorporating GluR2(N) are highly $\mathrm{Ca}^{2+}$-permeable. This mouse shows an increase in the relative $\mathrm{Ca}^{2+}$ permeability of neuronal AMPA receptors and an increase in total GluR2 protein expression levels, and displays a striking phenotype consisting of late-onset, selective motoneuron degeneration. This raises the possibility that certain forms of naturally occurring motoneuron disease may arise from alterations in AMPA receptor structure and function.

\section{REFERENCES}

Albuquerque C, Lee CJ, Jackson AC, MacDermott AB (1999) Subpopulations of GABAergic and non-GABAergic rat dorsal horn neurons express $\mathrm{Ca}^{2+}$-permeable AMPA receptors. Eur $\mathrm{J}$ Neurosci $11: 2758-2766$

Bar-Peled O, O'Brien RJ, Morrison JH, Rothstein JD (1999) Cultured motoneurons possess calcium-permeable AMPA receptors. NeuroReport 10:855-859.

Bleakman D, Ballyk BA, Schoepp DD, Palmer AJ, Bath CP, Sharpe EF, Woolley ML, Bufton HR, Kamboj RK, Tarnawa I, Lodge D (1996) Activity of 2,3-benzodiazepines at native rat and recombinant human glutamate receptors in vitro: stereospecificity and selectivity profiles. Neuropharmacology 35:1689-1702.

Bochet P, Audinat E, Lambolez B, Crépel F, Rossier J, Iino M, Tsuzuki K, Ozawa S (1994) Subunit composition at the single-cell level explains functional properties of a glutamate-gated channel. Neuron 12:383-388.

Brorson JR, Manzolillo PA, Miller RJ (1994) $\mathrm{Ca}^{2+}$ entry via AMPA/KA receptors and excitotoxicity in cultured cerebellar Purkinje cells. J Neurosci 14:187-197.

Brorson JR, Manzolillo PA, Gibbons SJ, Miller RJ (1995) AMPA receptor desensitization predicts the selective vulnerability of cerebellar Purkinje cells to excitotoxicity. J Neurosci 15:4515-4524.

Brorson JR, Zhang Z, Vandenberghe W (1999) $\mathrm{Ca}^{2+}$ permeation of AMPA receptors in cerebellar neurons expressing GluR2. J Neurosci 19:9149-9159.

Burnashev N, Monyer H, Seeburg PH, Sakmann B (1992) Divalent ion permeability of AMPA receptor channels is dominated by the edited form of a single subunit. Neuron 8:189-198.

Carriedo SG, Yin HZ, Weiss JH (1996) Motor neurons are selectively vulnerable to AMPA/KA receptor-mediated injury in vitro. J Neurosci 16:4069-4079.

Dean JA (1992) In: Lange's handbook of chemistry, Ed 14. New York: McGraw-Hill.

Egebjerg J, Heinemann SF (1993) $\mathrm{Ca}^{2+}$ permeability of unedited and edited versions of the kainate selective glutamate receptor subunit GluR6. Proc Natl Acad Sci USA 90:755-759.

Escurat M, Djabali K, Gumpel M, Gros F, Portier MM (1990) Differential expression of two neuronal intermediate-filament proteins, peripherin and the low-molecular-mass neurofilament protein (NF-L), during the development of the rat. J Neurosci 10:764-784.

Feldmeyer D, Kask K, Brusa R, Kornau HC, Kolhekar R, Rozov A, Burnashev N, Jensen V, Hvalby O, Sprengel R, Seeburg PH (1999) Neurological dysfunctions in mice expressing different levels of the Q/R site-unedited AMPAR subunit GluR-B. Nat Neurosci 1:57-64.

Furuyama T, Kiyama H, Sato K, Park HT, Maeno H, Takagi H, Tohyama M (1993) Region-specific expression of subunits of ionotropic glutamate receptors (AMPA-type, KA-type and NMDA receptors) in the rat spinal cord with special reference to nociception. Brain Res Mol Brain Res 18:141-151.

Geiger JR, Melcher T, Koh DS, Sakmann B, Seeburg PH, Jonas P, Monyer H (1995) Relative abundance of subunit mRNAs determines gating and $\mathrm{Ca}^{2+}$ permeability of AMPA receptors in principal neurons and interneurons in rat CNS. Neuron 15:193-204.

Goldstein PA, Lee CJ, MacDermott AB (1995) Variable distributions of $\mathrm{Ca}^{2+}$-permeable and $\mathrm{Ca}^{2+}$-impermeable AMPA receptors on embryonic rat dorsal horn neurons. J Neurophysiol 73:2522-2534.

Grossman SD, Wolfe BB, Yasuda RP, Wrathall JR (1999) Alterations in AMPA receptor subunit expression after experimental spinal cord contusion injury. J Neurosci 19:5711-5720.

Hollmann M, Heinemann S (1994) Cloned glutamate receptors. Annu Rev Neurosci 17:31-108.

Hollmann M, Hartley M, Heinemann S (1991) $\mathrm{Ca}^{2+}$ permeability of KA-AMPA-gated glutamate receptor channels depends on subunit composition. Science 252:851-853.

Hugon J, Vallat JM, Spencer PS, Leboutet MJ, Barthe D (1989) Kainic acid induces early and delayed degenerative neuronal changes in rat spinal cord. Neurosci Lett 104:258-262.

Hume RI, Dingledine R, Heinemann SF (1991) Identification of a site in glutamate receptor subunits that controls calcium permeability. Science 253:1028-1031.

Iino M, Ozawa S, Tsuzuki K (1990) Permeation of calcium through excitatory amino acid receptor channels in cultured rat hippocampal neurones. J Physiol (Lond) 424:151-165.

Iino M, Mochizuki S, Ozawa S (1994) Relationship between calcium permeability and rectification properties of AMPA receptors in cultured rat hippocampal neurons. Neurosci Lett 173:14-16.

Ikonomidou C, Qin Qin Y, Labruyere J, Olney JW (1996) Motor neuron degeneration induced by excitotoxin agonists has features in common with those seen in the SOD-1 transgenic mouse model of amyotrophic lateral sclerosis. J Neuropathol Exp Neurol 55:211-224.

Jakowec MW, Yen L, Kalb RG (1995) In situ hybridization analysis of AMPA receptor subunit gene expression in the developing rat spinal cord. Neuroscience 67:909-920.

Jonas P, Burnashev N (1995) Molecular mechanisms controlling calcium entry through AMPA-type glutamate receptor channels. Neuron 15:987-990.

Jonas P, Racca C, Sakmann B, Seeburg PH, Monyer H (1994) Differences in $\mathrm{Ca}^{2+}$ permeability of AMPA-type glutamate receptor channels in neocortical neurons caused by differential GluR-B subunit expression. Neuron 12:1281-1289.

Kolhekar R, Kornau HC, Seeburg PH, Bresink I, Müller G, Taylor J, Turski L (1998) Late-onset neurological symptoms in transgenic mice expressing a calcium-permeable GluR-B subunit. Soc Neurosci Abstr 24:1517.

Lambolez B, Audinat E, Bochet P, Crépel F, Rossier J (1992) AMPA receptor subunits expressed by single Purkinje cells. Neuron 9:247-258.

Lerma J, Morales M, Ibarz JM, Somohano F (1994) Rectification properties and $\mathrm{Ca}^{2+}$ permeability of glutamate receptor channels in hippocampal cells. Eur J Neurosci 6:1080-1088.

Mayer ML, Westbrook GL (1987) Permeation and block of $N$-methyl-Daspartic acid receptor channels by divalent cations in mouse cultured central neurons. J Physiol (Lond) 394:501-527.

Morrison BM, Janssen WG, Gordon JW, Morrison JH (1998) Light and electron microscopic distribution of the AMPA receptor subunit, GluR2, in the spinal cord of control and G68R mutant superoxide dismutase transgenic mice. J Comp Neurol 395:523-534.

Partin KM, Patneau DK, Winters CA, Mayer ML, Buonanno A (1993) Selective modulation of desensitization at AMPA versus kainate receptors by cyclothiazide and concanavalin A. Neuron 11:1069-1082.

Pellegrini-Giampietro DE, Fan S, Ault B, Miller BE, Zukin RS (1994) Glutamate receptor gene expression in spinal cord of arthritic rats. J Neurosci 14:1576-1583.

Pellegrini-Giampietro DE, Gorter JA, Bennett MV, Zukin RS (1997) The GluR2 (GluR-B) hypothesis: $\mathrm{Ca}^{2+}$ permeable AMPA receptors in neurological disorders. Trends Neurosci 20:464-470.

Petralia RS, Wang YX, Mayat E, Wenthold RJ (1997) Glutamate receptor subunit 2-selective antibody shows a differential distribution of calcium-impermeable AMPA receptors among populations of neurons. J Comp Neurol 385:456-476.

Pruss R, Akeson RL, Racke MM, Wilburn JL (1991) Agonist-activated cobalt uptake identifies divalent cation-permeable kainate receptors on neurons and glial cells. Neuron 7:509-518.

Rosenmund C, Stern-Bach Y, Stevens CF (1998) The tetrameric structure of a glutamate receptor channel. Science 280:1596-1599. 
Rothstein JD (1996) Excitotoxicity hypothesis. Neurology 47 [Suppl 2]:S19-S25.

Rothstein JD, Jin L, Dykes-Hoberg M, Kuncl RW (1993) Chronic inhibition of glutamate uptake produces a model of slow neurotoxicity. Proc Natl Acad Sci USA 90:6591-6595.

Seeburg PH (1993) The molecular biology of mammalian glutamate receptor channels. Trends Neurosci 16:359-365.

Shaw PJ, Ince PG (1997) Glutamate, excitotoxicity and amyotrophic lateral sclerosis. J Neurol 244 [Suppl 2]:S3-S14.

Sommer B, Köhler M, Sprengel R, Seeburg PH (1991) RNA editing in brain controls a determinant of ion flow in glutamate-gated channels. Cell 67:11-19.

Temkin R, Lowe D, Jensen P, Hatt H, Smith DO (1997) Expression of glutamate receptor subunits in alpha-motoneurons. Brain Res Mol Brain Res 52:38-45.

Tölle TR, Berthele A, Zieglgänsberger W, Seeburg PH, Wisden W (1993) The differential expression of 16 NMDA and non-NMDA receptor subunits in the rat spinal cord and in periaqueductal gray. J Neurosci 13:5009-5028.

Tomiyama M, Rodriguez-Puertas R, Cortes R, Christnacher A, Sommer B, Pazos A, Palacios JM, Mengod G (1996) Differential regional distribution of AMPA receptor subunit messenger RNAs in the human spinal cord as visualized by in situ hybridization. Neuroscience 75:901915.

Vandenberghe W, Van Den Bosch L, Robberecht W (1998a) Glial cells potentiate kainate-induced neuronal death in a motoneuron-enriched spinal coculture system. Brain Res 807:1-10.

Vandenberghe W, Van Den Bosch L, Robberecht W (1998b) Tissuetype plasminogen activator is not required for kainate-induced motoneuron death in vitro. NeuroReport 9:2791-2796.

Virgo L, Samarasinghe S, de Belleroche J (1996) Analysis of AMPA receptor subunit mRNA expression in control and ALS spinal cord. NeuroReport 7:2507-2511.

Washburn MS, Numberger M, Zhang S, Dingledine R (1997) Differential dependence on GluR2 expression of three characteristic features of AMPA receptors. J Neurosci 17:9393-9406.

Williams TL, Day NC, Ince PG, Kamboj RK, Shaw PJ (1997) Calciumpermeable alpha-amino-3-hydroxy-5-methyl-4-isoxazole propionic acid receptors: a molecular determinant of selective vulnerability in amyotrophic lateral sclerosis. Ann Neurol 42:200-207.

Yin HZ, Park DD, Lindsay AD, Weiss JH (1995) Spinal cord neurons are vulnerable to rapidly triggered kainate neurotoxicity in vitro. Brain Res 689:265-270. 